\title{
PERENCANAAN PAKET WISATA TIRTA DI KABUPATEN BULELENG
}

\author{
Luh Putu Swandewi \\ I Putu Sudana \\ Yayu Indrawati \\ Email : abella82@ymail.com \\ PS. S1 Industri Perjalanan Wisata \\ Fakultas Pariwisata UNUD
}

\begin{abstract}
Buleleng has variety attraction for tourism industry, such as natural and cultural potencies of tourism destination and most of it, is about marine tourism but there are none of them providing water tour packages. The purpose of this field study is to identify the marine tourism potency in Buleleng Regency and plan a marine package tour using distribution channel model of the marine package tour which have to planning for new brand on package tour in Bali, especially about the promotion for alternative tourism of the marine tour package must be increased the tourist arrivals to Buleleng Regency. The final result of this study indicated from the observations which the potencies of marine tourism in Buleleng has not been developed and get attention, especially from the local government with required the promotion for marine tourism attraction in Buleleng Regency. In addition of the marine tourism package can be used for the local society and make satisfied of the package tour for tourist who arriving for holiday in Buleleng Regency.
\end{abstract}

Keywords: Marine Tourism, Potency, Tour Package.

\section{PENDAHULUAN}

Wisata tirta merupakan potensi wisata yang terdapat hampir di seluruh wilayah Indonesia dan perlu di kembangkan secara efektif dengan memperhatikan dampak lainnya terhadap lingkungan. Bali merupakan salah satu wilayah pariwisata yang mengandalkan potensi wisata tirta, namun pengembangan dari wisata tirta ini belum terlihat maksimal antara wilayahwilayah di Bali lainnya. Kabupaten Buleleng termasuk dalam daerah pariwisata yang didominasi oleh potensi wisata tirta dan hal tersebut dapat dilihat dari adanya kawasan pariwisata Kalibukbuk yang lebih dikenal dengan kawasan Lovina. Kabupaten Buleleng juga mempunyai jalur perhubungan laut, yaitu dermaga pelabuhan Celukan Bawang di Kecamatan Gerokgak dan pelabuhan tradisional
Sangsit di Kecamatan Sawan yang dapat digunakan untuk kegiatan wisata tirta.

Melihat segala potensi wisata tirta tersebut, maka sangat diperlukan pengembangan dalam hal pengemasan paket wisata tirta untuk mempermudah wisatawan dalam menikmati kegiatan wisata tirta di Kabupaten Buleleng karena selama ini belum terdapat pengemasan secara khusus oleh biro-biro perjalanan di bali dalam paket wisata tirta di Kabupaten Buleleng, selain itu minat wisatawan terhadap kunjungannya ke Bali juga banyak didasari oleh keinginan untuk menikmati wisata air (tirta) yang ada di Bali dan hal tersebut merupakan peluang usaha tersendiri untuk mengembangkan pariwisata di bidang wisata tirta dan tahapantahapan pengemasan ini, didasari atas adanya unsur kepariwisataan seperti something to do, 
something to buy, something see yang nantinya akan digunakan dalam pengemasan paket wisata tirta di Kabupaten Buleleng.

\section{TINJAUAN PUSTAKA}

Sihite (2000) menjelaskan bahwa pengertian wisatawan terbagi atas dua jenis wisatawan, yaitu wisatawan nusantara dan wisatawan mancanegara. Pengertian pertama mengenai wisatawan nusantara adalah wisatawan dalam negeri sedangkan wisatawan mancanegara merupakan warga negara asing yang berasal dari suatu negara dan melakukan perjalanan wisata keluar lingkungan tempat tinggal dari negaranya ke negara lain.

Pendit (1994) menjelaskan bahwa potensi wisata merupakan potensi yang terdapat pada suatu daerah sehingga potensi wisata tersebut dapat dikembangkan menjadi daya tarik wisata atau daerah tujuan wisata yang dapat dijadikan obyek kunjungan wisatawan ketika melakukan kegiatan wisata. Secara umum potensi wisata terbagi atas dua hal, yaitu potensi budaya merupakan potensi yang sudah ada dan berkembang di lingkungan masyarakat, seperti kesenian, adat-istiadat dan sebagainya. Serta potensi alamiah yaitu potensi yang cenderung pada potensi fisik seperti keadaan geografi maupun alam.

Pendit (2003) menyatakan bahwa pengertian wisata tirta merupakan jenis pariwisata yang berkaitan dengan kegiatan olahraga air seperti di pantai, danau, sungai, teluk maupun kegiatan lain yang dapat dilakukan di laut lepas seperti berlayar maupun menyelam, dan selain itu dapat dikatakan bahwa wisata tirta merupakan segala aktivitas wisata yang menjadikan sumber daya alam pantai, danau, teluk, sungai dengan segala potensinya sebagai daya tarik wisata. Darmadjati (2001) memberikan pengertian bahwa wisata tirta merupakan pemanfaatan pariwisata atas kawasan air yang dikembangkan secara profesional sehingga menjadi tempat tujuan wisata yang menarik.

Yoeti (1997) menjelaskan bahwa paket wisata merupakan suatu perjalanan wisata yang telah direncanakan dan disusun berdasarkan acara wisata, dimana perjalanan wisata ini diselenggarakan oleh biro perjalanan maupun agen perjalanan dengan resiko dan tanggung jawab perusahaan baik berupa jenis acara, waktu yang dihabiskan untuk berwisata dan tempat yang akan dikunjungi. Selain itu akomodasi, transportasi, serta makanan juga telah ditentukan jumlah satuan harganya oleh biro perjalanan. Mengingat karakteristik wisatawan yang beragam, hal yang perlu diperhatikan dalam penyusunan paket wisata yaitu dengan selalu berorientasi kepada konsumen sebab paket wisata harus dibuat sesuai dengan kondisi wisatawan, baik dalam hal motivasi, karakteristik atau kemampuan daya beli wisatawan (Suyitno, 1999).

\section{METODE PENELITIAN}

Penelitian ini dilakukan di 4 wilayah yaitu Desa Kalibukbuk, Desa Temukus, Desa Banjar dan Desa Seririt yang terletak di Kabupaten Buleleng. Ruang lingkup yang akan digunakan untuk pedoman dan batasan dalam penelitian ini terbagi atas tiga hal yaitu, potensi (fisik dan non fisik), perencanaan paket wisata (bentuk uraian dan grafik) dan model saluran distribusi pariwisata. Teknik dalam pengumpulan data dilakukan dengan cara observasi, wawancara dan studi kepustakaan. Adapun penentuan informan dalam penelitian ini dilakukan dengan teknik purposive sampling yaitu orang-orang yang akan menjadi informan ditentukan sebanyak satu orang dari masing-masing objek wisata, selain itu, informan akan terdiri dari pelaku pariwisata setempat, tokoh masyarakat dan penelitian ini menggunakan analisis deskriptif kualitatif yaitu memahami segala kondisi secara terperinci khususnya dalam pengemasan paket, dimana hasil dari analisa akan dilakukan dengan menyajikan hasil wawancara serta observasi terhadap potensi yang ditemukan di lapangan yang pada penelitian ini terletak di empat desa yang terdapat di Kabupaten Buleleng.

\section{HASIL DAN PEMBAHASAN}

Potensi Wisata di Kabupaten Buleleng yang dijadikan sebagai Paket Wisata Tirta Pantai Lovina

Pantai lovina berada di bagian utara pulau Bali, tepatnya di Desa Kalibukbuk yang berjarak sekitar $20 \mathrm{Km}$ ke arah barat kota Singaraja. 
Kunjungan wisatawan ke Lovina juga banyak karena selain dapat melihat pantai yang masih alami, wisatawan akan disuguhkan oleh atraksi lumba-lumba yang akan bermunculan di pagi hari dan dengan menyewa perahu nelayan lokal dan wisatawan dapat mendekati lumba-lumba tersebut di tengah laut. Di kawasan Lovina telah banyak terdapat akomodasi untuk menginap seperti Inn atau cottages, tentunya dengan harga yang sangat terjangkau.

\section{Air Terjun Singsing}

Wisata tirta air terjun singsing terletak di Banjar Labuhan Haji, Desa Temukus, Kecamatan Banjar. Keberadaan air terjun ini masih sangat alami dan wisatawan dapat menikmati pemandangan yang asri, bersantai di dekat air terjun serta melihat hamparan pantai Lovina dari kejauhan. Selain itu, di kawasan air terjun singsing terdapat sebuah monumen yaitu Monumen Belanda. Monumen ini didirikan untuk mengenang seorang perwira besar Belanda yang gugur dalam perang Banjar pada tahun 1868, sehingga air terjun ini dapat dikatakan sebagai objek wisata alam dan sejarah yang menarik untuk dikunjungi oleh wisatawan.

\section{Air Panas Banjar}

Air panas ini terletak di Desa Banjar sekitar 24 kilometer di sebelah barat Singaraja. Disepanjang perjalanan dari tempat parkir ke kolam air panas terdapat berbagai macam penjual toko oleh-oleh khas Bali. Sumber mata air di tempat ini, diperkirakan berusia ratusan tahun dan dipercaya dapat menyembuhkan penyakit. Adapun fasilitas pendukung di air panas banjar seperti ruang ganti pakaian, sehingga wisatawan yang berkunjung tidak akan merasa resah ketika ingin mandi atau berganti pakaian. Di lokasi wisata tirta ini, juga terdapat restoran yang biasanya dimanfaatkan pengunjung untuk menunggu anak-anak bermain dikolam maupun makan selepas berendam.

\section{Perkebunan Anggur Seririt}

Desa Seririt banyak memiliki kebun anggur yang sangat menarik untuk dikunjungi. Perkebunan anggur desa Seririt terletak di atas daerah perbukitan Singaraja tepatnya di jalan Puputan, Singaraja. Salah satu perkebunan yang cukup terkenal di daerah ini yaitu perkebunan anggur Indico. Di tempat ini, wisatawan bisa menikmati pemandangan khas pegunungan dan melihat langsung kegiatan para petani yang merawat ataupun memanen anggur. Wisatawan akan diperbolehkan masuk ke dalam pabrik pengolahan anggur dan melihat proses pengolahan anggur sebelum menjadi minuman beralkohol seperti white wine, red wine, bir dan wishki.

\section{Perencanaan Kemasan Paket Wisata Tirta di Kabupaten Buleleng Full Day Tour "Exotic Tour of Buleleng"}

Perjalanan diawali dari Pullman Bali Legian Nirwana Hotel sekitar Pukul 03.30 WITA menuju pantai Lovina. Jarak yang di tempuh kurang lebih $20 \mathrm{Km}$ ke arah barat kota Singaraja dan wisatawan akan disediakan breakfast box untuk menikmati sarapan diperjalanan menuju lovina. Sesampainya di lovina, persiapan akan dilakukan dengan menggunakan life jacket lalu untuk menuju perahu. Setelah 20 menit perjalanan ke tengah laut, wisatawan akan menyadari bahwa banyak terdapat perahu-perahu lain yang ingin melihat lumba-lumba dan tentunya atraksi lumba-lumba yang hidup bebas di laut bebas akan memukau semua orang. Atraksi lumba-lumba ini akan berlangsung kurang lebih selama satu jam dan setelah itu, perjalanan akan dilanjutkan ke warung yang cukup terkenal di daerah tersebut (Warung Apel) untuk tea time sebelum perjalanan akan dilanjutkan ke air terjun singsing.

Air Terjun Singsing terletak di Desa Temukus, Kecamatan Banjar, sekitar tiga kilometer dari Lovina. Jalan yang dilalui untuk menuju ke air terjun tersebut bisa dikatakan sangat baik, jadi tidak akan menyulitkan wisatawan untuk berjalan. Wisatawan akan merasakan alam yang asri dan hamparan pantai Lovina dari kejauhan serta melihat monument Belanda yang ada di dekat sana. Setelah puas menikmati keindahan air terjun singsing maka perjalanan dilanjutkan ke pemandian air panas Banjar. Di tempat tersebut, wisatawan bisa memanjakan diri dengan berendam air panas yang dipercaya dapat menyembuhkan penyakit seperti penyakit kulit dan keindahan sekitar 
lokasi akan membuat wisatawan merasa nyaman karena didukung oleh keadaan alam yang begitu asri.

Melakukan perjalanan wisata tentunya tidak akan sempurna tanpa berbelanja oleh-oleh khas daerah yang dikunjungi. Oleh sebab itu, perjalanan terakhir dari paket wisata tirta ini adalah mengunjungi salah satu kebun anggur di desa Seririt. Kebun anggur tersebut bernama kebun anggur Indico yang terletak di desa Seririt, tepatnya di jalan Puputan-Singaraja. Tempat tersebut mampu menghasilkan produk anggur yang berkualitas dengan merek indico wine bali dan wisatawan boleh membeli anggur ataupun membeli Indico Wine Bali untuk dibawa pulang. Selain itu, wisatawan akan menikmati makan siangnya di kebun anggur Indico.

\section{Model Saluran Distribusi Paket Wisata Tirta di Kabupaten Buleleng}

Hasil kemasan produk wisata yang dibuat berupa paket wisata "Exotic Tour of Buleleng" di Kabupaten Buleleng yang berupa paket wisata tirta akan dimodifikasi dan dipasarkan oleh biro perjalanan wisata mitra baik secara langsung kepada wisatawan. Sistem keberlanjutan distribusi pemasaran produk wisata tirta yang dirancang di Kabupaten Buleleng. Paket wisata tirta di Kabupaten Buleleng yang telah dikemas, nantinya akan dipasarkan kepada pelaku-pelaku pariwisata seperti biro perjalanan mitra yang ada dalam saluran distribusi yaitu Perama Tour Singaraja. Adapun hal yang akan dilakukan guna mempromosikan paket wisata tirta di Kabupaten Buleleng yaitu dengan penyebaran bosur paket wisata tirta, membuat kontrak-kontrak dengan biro perjalanan wisata lainnya seperti biro perjalanan yang berada di Kabupaten Buleleng ataupun sekitar Kuta.

\section{SIMPULAN DAN SARAN Simpulan}

Berdasarkan pembahasan dalam penelitian tentang perencanaan paket wisata tirta di Kabupaten Buleleng dapat disimpulkan bahwa potensi wisata tirta yang akan dikemas terdiri dari kawasan Pantai Lovina yang mempunyai daya tarik atraksi lumba-lumba, menjelajah alam di Air Terjun Singsing, memanjakan diri dengan berendam air panas di sumber Air Panas Banjar dan tidak lupa dengan wisata belanja sambil menikmati exotika kebun anggur di Seririt. Paket wisata tirta yang dikemas adalah "Exotic Tour of Buleleng" yang dimana paket tersebut diharapkan dapat membantu untuk mengangkat kembali citra (image) dari potensi-potensi yang ada sehingga dapat mendukung pengembangan daya tarik wisata di Kabupaten Buleleng, mengingat fluktuasi kunjungan wisatawan yang beragam terhadap kunjungan ke objek wisata di Kabupaten Buleleng saat ini dan dipasarkan dengan saluran distribusi pariwisata dengan kerjasama bersama dengan biro perjalanan Perama Tour \& Travel selaku penyelenggara, pemodifikasi paket maupun penyedia sarana transportasi.

\section{Saran}

Kabupaten Buleleng pada dasarnya terdiri dari berbagai lapisan sosial. Pemerintah dan pelaku wisata dapat menyediakan dan membenahi fasilitas-fasilitas pendukung yang dapat memberikan kenyamanan pada wisatawan seperti: toilet umum, tempat sampah, parkir, papan informasi dan peraturan serta membuat paket wisata tirta yang menarik sehingga tak muncul kejenuhan akan paket-paket wisata yang telah ada. Hendaknya dalam membuat paket wisata, lebih memperhatikan dan memberdayakan keterlibatan masyarakat lokal sehingga tingkat kesejahteraan di Kabupaten Buleleng dapat diangkat dengan menjaga kelestarian daya tarik wisata tirta agar menciptakan keindahan yang tetap alami sehingga memberikan kesan positif pada wisatawan terhadap kunjungannya ke daya tarik wisata tersebut.

\section{DAFTAR PUSTAKA}

Damardjati, RS. 2001. Istilah-istilah Dunia Pariwisata. Jakarta: Pradnya Paramita

Pendit, S. Nyoman. 1994. Ilmu Pariwisata, Sebuah Pengantar Perdana. Jakarta : PT Pradnya Paramitha 2003. Ilmu Pariwisata. PT. Pradnya Paramita. Jakarta.

Sihite, Richard. 2000. Tourism Industry (Kepariwisataan). Surabaya: SIC 
Jurnal IPTA

ISSN : 2338-8633

Vol. 2 No. 1, 2014

Suyitno. 1999. Perencanaan Wisata. Yoeti,Oka A. 1997. Perencanaan dan Yogyakarta. Pengembangan Pariwisata. Jakarta. 